Using a Developmental-relationship-based Approach for Improving the Joint Attention of a Child with Autism: A Single-case Design

Lia M. Boediman ${ }^{\mathrm{a}} *$ and Mayang Gita Mardian ${ }^{\mathrm{b}}$

${ }^{a}$ Department of Developmental Psychology, Faculty of Psychology, Universitas Indonesia, Depok, Indonesia; ${ }^{b}$ Faculty of Psychology, Universitas Indonesia, Depok, Indonesia

*Corresponding author:

Lia M. Boediman

Developmental Psychology Department

Faculty of Psychology, Universitas Indonesia

Jl. Lkr. Kampus Raya, Depok, Jawa Barat

Indonesia, 16424

Tel.: +62 217270004

Email address: 1boediman72@gmail.com 


\title{
Using a Developmental-relationship-based Approach for Improving the Joint Attention of a Child with Autism: A Single-case Design
}

\begin{abstract}
This single-case study examined the effectiveness of the developmental-relationshipbased approach in improving the joint attention of a child with autism. This study included one participant, a boy aged 7 years and 4 months. Two components of joint attention were measured: response to joint attention (RJA) and initiating joint attention (IJA). An adapted version of the Early Social Communication Scale was used to compare the child's joint attention skill before and after the intervention, and the Functional Emotional Assessment Scale was used to measure the child's functional capacity for emotional development. A pre-post design with multiple baselines was employed to quantify changes in joint attention and developmental capacity. A baseline study was conducted over three consecutive days. Nine intervention sessions were conducted and consisted of two psycho-educational sessions with the child's caregiver and seven direct intervention sessions with the child. The results of the study indicated that the child's participation in IJA has increased even though his participation in RJA has decreased. The decrease in the number of engagements in RJA does not necessarily indicate a lack of improvement in joint attention skills. On the contrary, this result suggested that the quality of the child's joint attention has improved because the child can initiate rather than merely respond to joint attention. This study shows that the quality of joint attention improves as a child with autism progresses from lower- to higher-level skills. Thus, this study provides promising result to improve the quality of joint attention skills in a sevenyear-and-four-month old child with autism.
\end{abstract}

Keywords: developmental-relationship-based intervention; joint attention; autism

\section{Introduction}

Joint attention is defined as the ability to "coordinate attention between interactive social partners with respect to objects or events to share an awareness of objects or events" (Mundy et al., 1986, p. 657). Joint attention consists of the following behaviors: 1) Sharing attention (e.g., through alternating eye contact); 2) Following the attention of another (e.g., following eye contact or a point); and 3) Directing the attention of another (e.g., pointing) (Dawson, et al., 2008). Children usually acquire these skills when they are 12 months of age (Dawson, et al., 2004). Joint attention plays a crucial role in the development of language, social, and learning skills in children (Charman, 2003). Furthermore, joint attention contributes to a child's ability to communicate and engage in back-and-forth interactions. Several studies have indicated that the lack of joint attention skill contributes to impaired social communication and social skill development in children with autism (Mundy et al., 1986).

Two types of joint attention exist: 1) Responding to joint attention (RJA); and 2) Initiating joint attention (IJA) (Charman \& Stone, 2006; Mundy and Sigman, 2006). RJA occurs when a child can follow and share the attention of others (Mundy, et al., in Mundy \& Newell, 2007). For example, when an adult is pointing to a certain object, the child can move his head to direct his attention to the object. In contrast to RJA, IJA occurs when the child attempts to direct other people's attention to things that interest him or when he tries to share an experience with other people (Scaife and Bruner, as cited in Mundy \& Burnette, 2005). IJA occurs when the child 
moves or makes eye contact to direct other people's attention toward himself, an object or event. Thus, IJA requires more complex behavior and is a higher-level skill than RJA.

To acquire joint attention, a child needs to develop these following foundational skills: 1) Shared attention, the ability to take interest or be curious in what other people are doing; 2) Shared affect, the ability to express and share one's emotions and experiences with others; and 3) Shared intention, the ability to intentionally direct other people's attention to accomplish a certain goal (Charman \& Stone, 2003). The development of these fundamental skills occurs naturally and easily in typically developing children but prove to challenging for children with autism.

The developmental-relationship-based approach is often used to improve the social skills and joint attention of children with autism. This intervention is a comprehensive approach that focuses on three main areas: 1) Functional emotional developmental capacity, 2) Individual differences, and 3) Relationship. Functional emotional developmental capacity is a basic foundational skill that consists of six stages: 1) Shared attention and regulation, 2) Engagement and relating, 3) Two-intentional communication, 4) Shared social problem solving, 5) Creating ideas, and 6) Building bridges between ideas (Greenspan \& Weider, 2006).

Individual differences refer to individual neurophysiological and biological make-up and system and individual ways of receiving, organizing, processing, and reacting to sensory information. An individual might be hypersensitive or hyposensitive to specific or combined sensory stimuli. Individual differences also refer to motor planning, or how an individual can plan and execute his/her actions (Greenspan \& Weider, 2006). Greenspan (1998) believed that individual differences contribute to a child's reaction to his/her environment. This reaction, in turn, influences how the environment treats the child. Thus, an awareness of the individual differences is necessary to enable caregivers and clinicians to interact effectively with the child.

A relationship is viewed as a vehicle that can nurture and foster healthy development in children. Through positive, supportive, and loving relationships, the caregiver can help the child attain a higher level of functional emotional development capacity by being attuned to the child's needs, strengths, and weaknesses. The caregiver will become more aware of what type of stimulation helps the child to be alert and calm versus dysregulated (Greenspan \& Weiner, 1999).

The central principle of developmental-relationship-based intervention is to encourage the caregiver to be an active play partner for their child. One way the caregiver can become an active play partner is to learn how to follow the child's lead. Following the child's lead does not mean allowing the child to do whatever they want. Instead, the caregiver attempts to interact with the child by using their interests (Greenspan \& Wieder, 2006). When a child engages in an activity that they are interested in, they tend to be more motivated to engage a caregiver in his/her play activity (Hess, 2013).

The developmental-relationship-based intervention approach has been selected as the most appropriate intervention for a child and their family because of the following reasons: 1) It is a comprehensive approach that considers the developmental capacity and individual differences of the child. Thus, the intervention can be specifically tailored to individual needs. 2) It incorporates play activity as a medium of change. 3) It incorporates the importance of a relationship. 4) It engages the caregiver throughout the entire process of intervention (Greenspan \& Wieder, 2006). 
The purpose of this study is to evaluate the effectiveness of developmental-relationshipbased intervention in improving the quality of joint attention in a child with autism.

\section{Methods}

\section{Participant}

The participant is a boy with autism aged 7 years and 4 months. When the child was 6 years old, he was referred to undergo assessment at the clinic of the Faculty of Psychology Universitas Indonesia, and he was diagnosed with autism. A year after the assessment, the child's family was approached by a clinician from the clinic and asked to participate in this study. The child is currently living with his grandmother, whereas his parents are living in different provinces because they were having difficulty raising the child. Thus, the grandmother agreed to take care of the child, and she became the primary caregiver of the child. She reported that the child is still having difficulty in relating and communicating with others. The child exhibits behavioral problems (angry outbursts, excessive crying, aggression, repetitive behavior, and lack of interest in a various activities). She reported that the child does not seem to be interested in interacting with other people. The child rarely responds to other people's invitation to interact with him, shows minimal eye contact, and does not respond when his name is called. Instead, he prefers to engage in solitary activities, such as playing with puzzles and arranging his toy cars and trains. He can be preoccupied with this solitary activity until someone interrupts him. He also has difficulty in expressing his wants and needs and comprehending what other people are saying. As a result, he often becomes frustrated and uses his behavior to communicate (crying, throwing tantrums, and hitting).

\section{Research Design}

A pre-post design with multiple baselines was used in this study. A baseline study was conducted over three consecutive days to measure the child's frequency and quality of JA (RJA and IJA) and functional developmental capacity.

\section{Measures}

The Early Social Communication Scales (Mundy et al., 2003) was adapted to measure the frequency and quality of the child's JA. The child's JA was measured while he interacted with his caregiver over a 20 min session. The researcher counted how often the child responded to joint attention (RJA) and how often the child initiated joint attention (IJA).

Table 1.

Observation Guideline of Joint Attention (adapted from Mundy et al., 1996)

$$
\text { Responding to Joint Attention (RJA) }
$$

\footnotetext{
1. Follows a proximal point

When the caregiver points to a certain object, child responds to the caregiver by moving his head and/or looking at the pointed object.

2. Follows what the caregiver is looking. The child moves his head and/or his eyes to indicate that he is looking at the object that is indicated by the caregiver.
}

\section{Makes eye contact}

When a child is holding a toy, he looks at the caregiver. When he drops the toy, he looks at the caregiver to see the caregiver's reaction.

\section{Alternate}

The child looks at the object, then looks at the caregiver. 
Table 1, cont

Observation Guideline of Joint Attention (adapted from Mundy et al., 1996)

\begin{tabular}{ll}
\hline Responding to Joint Attention $(\boldsymbol{R J A})$ & \multicolumn{1}{c}{ Initiating Joint Attention (IJA) } \\
\hline & $\begin{array}{l}\text { 3. Pointing } \\
\text { The child points to an object using his index finger } \\
\text { with/without eye contact. }\end{array}$ \\
$\begin{array}{l}\text { 4. Showing/sharing } \\
\text { The child places the object directly in front of the caregiver's } \\
\text { face. }\end{array}$ \\
\hline
\end{tabular}

The Functional Emotional Assessment Scale (FEAS) created by Greenspan et al. (2001) was used to identify the child's functional developmental capacity. The assessment takes 15-20 min to complete and involves engaging the caregiver in natural play interaction with the child by using various toys, such as sensory toys (i.e., toys with different textures, size, and sounds) and symbolic toys (i.e., cooking toys, human/animal figures, and dolls). The scoring consists of a Likert scale with scores of 0 to 2 . A score of 0 indicates that the behavior is rarely observed, a score of 1 indicates that the behavior is sometimes observed, and a score of 2 indicates that the behavior is often observed.

The validity and reliability of both of these rating scales have not yet been studied. Thus, their validity and reliability have not yet been confirmed.

\section{Procedure}

The study consisted of four phases: pre-assessment, assessment, intervention, and postintervention. A total of 16 sessions were conducted. The sessions included three pre-assessment sessions, three assessment sessions, two psycho-educational sessions, seven intervention sessions, and one post-intervention session.

Pre-assessment phase. During this phase, researcher reviewed all previously collected data, including the results of previous assessment. The researcher contacted the caregiver to inquire if the caregiver is interested in participating in this study. After the caregiver agreed to participate in this study, the researcher interviewed the caregiver and observed the child to ensure the accuracy of all data.

Assessment phase. During this phase, the child's functional developmental capacity was identified through observation with FEAS. The caregiver was asked to engage in a 20 min play activity with the child. The play activity was videotaped. The researcher also observed and measured the child's frequency and quality of interaction by using adapted version of the Early Social Communication Scale and counted the number of back-and-forth interactions (circles of communication) between the caregiver and the child.

Intervention phase. During this phase, the researcher provided two psycho-educational sessions to the caregiver about the developmental-relationship-based approach and techniques that will be used to improve the child's JA. Each psycho-educational session lasted for approximately 90 min. After psycho-educational sessions with the caregiver, the developmental-relationship-based intervention was applied. Seven intervention sessions were implemented, with each session lasting for $\pm 90 \mathrm{~min}$. Each intervention session consisted of the following activities: 
1) Review session for $20 \mathrm{~min}$. The goal and the strategies that will be used to increase a child's JA, and/or the homework session were discussed during the review session.

2) Implementation of developmental-relationship-based intervention for $40 \mathrm{~min}$. The 40 min intervention session was divided into two segments. During the first $20 \mathrm{~min}$, the caregiver was asked to interact with the child without coaching while the researcher observed the session. This session was then followed by a 20 min intervention session with coaching from the researcher.

3) Debriefing session for $20-30 \mathrm{~min}$. The purpose of this session is to review the implementation of the intervention session (i.e. challenges, strengths, etc.) and to provide a caregiver with homework assignment to practice with the child.

Post-intervention phase. During this phase, the researcher would ask the caregiver to engage in 20 min of play activity with the child. The session was videotaped. The researcher would review the video for observation and for scoring the FEAS and Early Social Communication Scale (adapted version).

\section{Data Analysis}

Baseline data were analyzed to obtain the child's mean RJA, IJA, and total JA scores. FEAS data were also analyzed to identify the child's pre-intervention functional developmental capacity. Data that were collected during each session were also analyzed to monitor the child's RJA, IJA, and total JA performance during each session. Furthermore, post-intervention data were analyzed and compared with pre-intervention data to evaluate the effectiveness of the intervention in improving JA.

\section{Results}

Graphic 1 summarizes the child's JA during the assessment, intervention, and postintervention sessions.

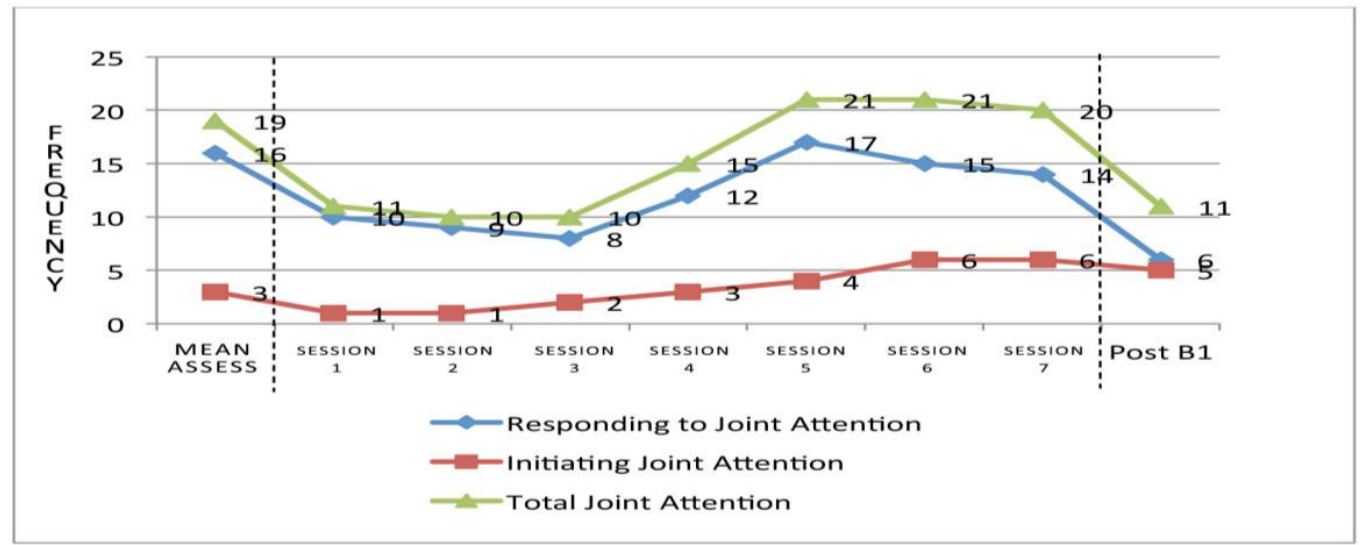

Figure 1. Participant's joint attention score from assessment to post intervention sessions 
The child's RJA and JA scores drastically decreased from the pre- to post-intervention sessions. His pre-intervention RJA score dropped by 9 points from 15 to 6 post-intervention. His JA score also dropped by 8 points from 19 (pre-intervention) to 11 (post-intervention). Comparing preintervention RJA and JA scores with post-intervention RJA and JA scores indicated a lack of improvement. However, comparing the scores from sessions 1 to session 7 of the intervention phase revealed that the child has made some improvements. The RJA score during session 1 (10) increased by 4 points or by $40 \%$ by session 7 (14). The highest RJA score of 17 was observed on session 7 and had increased by $70 \%$.

Total JA decreased by 8 from the score of 19 (pre-intervention) to 11 (post-intervention) but increased during session 5 and 6 . The child's JA score pattern seems to mimic his RJA score pattern, wherein scores drastically dropped at the beginning of the intervention sessions (session 1,2 and 3) but slowly increased during sessions 4, 5, and 6.

By contrast, the child's IJA score improved from pre- to post-intervention. Specifically, his IJA scores slightly dropped from 3 (pre-intervention) to 1 (session 1 and 2), increased to 2 (session 3 ), and continued to increase slowly but steadily to 6 (session 7). Overall, the child's IJA scores increased by 2 points from pre- to post-intervention and by $500 \%$ from session 1 (score 1) to session 7 (score 5).

Although the data indicated that his RJA score decreased between pre- and post-intervention sessions, the child's IJA score showed some improvement. The child displayed an ability to engage in longer interaction with his grandmother, and he seemed to be able to share his interests with other people. He can now initiate joint attention rather than merely respond to joint attention. This behavior showed that the child has acquired high-level joint attention skills.

Table 2.

Participant's functional developmental capacity from pre to post sessions

\begin{tabular}{|c|c|c|c|c|c|c|}
\hline Stages & $\begin{array}{c}\text { Max } \\
\text { Scores }\end{array}$ & $\begin{array}{c}\text { Assess } \\
1\end{array}$ & $\begin{array}{l}\text { Assess } \\
2\end{array}$ & $\begin{array}{l}\text { Assess } \\
3\end{array}$ & $\begin{array}{l}\text { Mean } \\
\text { Assess } \\
\text { (A1) }\end{array}$ & $\begin{array}{l}\text { Post- } \\
\text { intervention } \\
\text { (B1) }\end{array}$ \\
\hline I. Self-regulation and interest in the world & 16 & 11 & 13 & 13 & 12 & 14 \\
\hline $\begin{array}{l}\text { II. Forming relationships, attachment, and } \\
\text { engagement }\end{array}$ & 16 & 10 & 9 & 8 & 9 & 11 \\
\hline III. Two-way purposeful communication & 8 & 6 & 5 & 5 & 5 & 6 \\
\hline $\begin{array}{l}\text { IV. Behavioral organization, problem-solving, } \\
\text { and internalization (a complex sense of self) }\end{array}$ & 4 & 2 & 2 & 2 & 2 & 4 \\
\hline V. Representational capacity (elaboration) & 14 & 1 & 2 & 1 & 1 & 3 \\
\hline $\begin{array}{l}\text { VI. Representational differentiation (building } \\
\text { bridges between ideas and emotional } \\
\text { thinking) }\end{array}$ & 10 & 0 & 0 & 0 & 0 & 1 \\
\hline Total & 68 & 30 & 31 & 29 & 30 & 39 \\
\hline
\end{tabular}

Table 2 indicates that that the child's functional developmental capacity increased from pre- to post-intervention. The child showed improvement in all six levels of functional developmental capacity. The child displayed an increase of 1 to 2 points in each developmental level with the highest increase ( 2 points) at levels I, II, IV, and V. At level I, the child displayed the ability to focus and attend to an activity for an extended duration. He was able to focus on one activity during playtime rather than aimlessly moving from one activity to another. He also showed enjoyment when he engaged in activity with other people. At level II, the child showed interest in what other people were doing and was able to engage in cooperative play. At level IV, the child engaged in numerous back-and-forth interactions with his grandmother. At level $\mathrm{V}$, the child was able to engage in symbolic and pretend play with his grandmother. This behavior indicates that he has broadened his interests and activities. 


\section{Discussion}

The results of this study suggested that the developmental-relationship-based approach may improve the quality of the joint attention of a child with autism. In this study, although the subject's post-intervention RJA frequency decreased, his post-intervention IJA frequency increased. The child performed considerably better on IJA than on RJA. IJA requires more complex and higher-level joint attention skills than RJA. To engage in IJA, the child has to initiate interaction. Sharing and engaging with other individuals require motivation and not only response to joint attention. Thus, IJA is not easy for a child with autism. Furthermore, the improvement in IJA is also reflected in the child's ability to socially interact with others. During interaction with other people, the child was able to express positive emotions. This ability may indicate that the quality of the child's joint attention has improved.

The developmental-relationship-based approach requires the active involvement of the caregiver. The caregiver needs to know the child very well (the child's strengths, weaknesses, interests, and disinterests, as well as the things that can stimulate and motivate or things over-stimulate the child) and should be attuned to his needs. This kind of understanding, however, requires patience. The caregiver needs to learn when to push and when to step back. These tasks are particularly difficult for a caregiver who is used to directing the child's behavior, is not used to engaging in playful activity with the child, and requires immediate results. Furthermore, implementing this approach can be challenging when the caregiver is under a lot of stress and does not have support from their family. In this study, the participant's caretaker stated numerous times that she feels so tired and stressed from coping with the child's behavior. She does not have support from the child's parents, and at times she feels overwhelmed. Her emotions were reflected by her interactions with the child: She sometimes became directive, impatient, and angry with the child. However, when she was in a better state (less stress) and when she received support from the researcher, she was able to be attuned and engaged playfully with the child. Unfortunately, given the living situation and high stress levels of the caregiver, this positive interaction did not occur consistently. This inconsistency affected the progress of the intervention.

Nevertheless, some progress was observed regardless of the family's difficult living situation and the short duration of intervention. The child can now initiate joint attention with others, engage in extended back-and-forth interactions, and express additional emotions. He has broadened his interests, and his focus has improved. Thus, the developmental-relationship based approach promises to improve the quality of joint attention in children with autism.

\section{References}

American Psychiatric Association. (1994). Diagnostic and statistical manual of mental disorders $4^{\text {th }}$ edition. Washington DC: Author.

American Psychiatric Association. (2013). Diagnostic and statistical manual of mental disorder $5^{\text {th }}$ edition. Washington, DC : Author.

Carpendale, J. I. M., \& Mulle, U. (2013). Social interaction and the development of knowledge. NY: Psychology Press.

Cervera, G. R., Romero, M. G. M., Mas, L. A., \& Delgado, F. M. (2010). In Williams, T. (ed.). Autism spectrum disorders - from genes to environment. Rijeka: InTech. 
Charman, T. (2003). Why is joint attention a pivotal skill in autism?. The Royal Society, 358, 315-324. doi: 10.1098/rstb.2002.1199.

Charman, T., \& Stone, W. (2006). Social communication development in autism spectrum disorder: early identification, diagnostic, and intervention. London, UK: The Guilford Press.

Cicchetti, D., \& Cohen, D. J. $\left(2006^{\mathrm{a}}\right)$. Developmental psychopathology $2^{\text {nd }}$ edition volume 1: Theory and Method. Hoboken: John Wiley \& Sons, Inc.

Cicchetti, D., \& Cohen, D. J. $\left(2006^{\mathrm{b}}\right)$. Developmental psychopathology $2^{\text {nd }}$ volume 3 . Hoboken: John Wiley \& Sons, Inc.

Dawson, G., \& Faja, S. (2008). Autism spectrum disorders: A developmental perspective. In Beauchaine, T. P. \& Hinshaw, S. P. (Eds.), Child and adolescent psychopathology (pp. 575-613). New Jersey: John Wiley \& Sons.

Dionne, M., \& Martini, R. (2011). Floor Time Play with a child with autism: A single-subject study. Canadian Journal of Occupational Therapy, 78(3), 196-203.

Fein, D., Barton,M., Eigsti, I., Kelley, E., Naigles, L., Schultz, R. T., \& Tyson, K. (2013). Optimal outcome in individuals with a history of autism. Journal of Child Psychology \& Psychiatry, 54, 195-205.

Gammeltoft, L., \& Nordenhof, M. D. (2007). Autism, play, \& social interaction. London, UK: Jessica Kingsley Publisher.

Gast, D. L. (2010). Single Subject Research Methodology in Behavioral Sciences. New York, NY: Routledge.

Greenspan, S. I. (2002). The secure child: helping our children feel safe and confident in a changing world. Cambridge: Da Capo Press.

Greenspan, S. I., De Gangi, G.A., \& Wieder, S. (2001). The Functional Emotional Assessment Scale (FEAS) for infancy and early childhood: Clinical \& research applications. Bethseda: ICDL.

Greenspan, S. I., \& Greenspan, N. T. (2010). The learning tree: overcoming learning disabilities from the ground up. Cambridge: De Capo Press.

Greenspan, S. I., \& Wieder, S. (1997). Developmental patterns and outcomes in infants and children with disorders in relating and communicating: a chart review of 200 cases of children with autistic spectrum diagnoses. The Journal of Developmental and Learning Disorders, 1(1).

Greenspan, S. I., \& Wieder, S. (1999). A functional approach to autistic spectrum disorder. Journal of The Association for Persons with Severe Handicaps, 24(3), 147-161.

Greenspan, S. I., \& Wieder, S. (1998). The child with special needs: encouraging intellectual and emotional growth. Cambridge, MA: Merlyoyd Lawrence Book.

Greenspan, S. I., \& Wieder, S. (2006). The child with special needs: anak berkebutuhan khusus (Mieke Gembirasari, Penerjemah.). Jakarta: Kanoman.

Greenspan, S. I., \& Wieder, S. (2010). Engaging autism: melangkah bersama autisme (Susi Purwoko, Penerjemah.). Jakarta: Citra Piramida Kencana.

Haugaard, J. J. (2008). Child psychopathology (Int. ed.). New York, NY: McGraw-Hill.

Hess, E. B. (2013). DIR / Floortime: evidence-based practice towards the treatment of autism and sensory processing disorder in children and adolescents. International Journal of Child Health and Human Development, 6(3), 267 - 274.

Hilton, J. C., \& Seal, B. C. (2007). Brief report: comparative ABA and DIR trials in twin brothers with autism. Journal of Autism and Developmental Disorder, 37, 1197-1201. doi: 10.1007/s10803-006-0258-Z

Hobson, J. A., Tarver, L., Beukens, N. \& Hobson, R.P. (2015). The relation between severity of autism and caregiver-child interaction: a study in the context of relationship development intervention. Journal of Abnormal Psychology. doi: 10.1007/s10802-015-0067-y

Jacobson, J. W., Mullick, J. A., \& Rojahn, J. (2007). Handbook of intellectual and Developmental disabilities. New York, NY: Springer.

Johnson, C. P. (2005). Early clinical characteristics of children with autism. In V. B. Gupta. (2005). Autism Spectrum Disorders in Children. New York: Marcel Decker.

Karst, J.S. \& Hecke, V. V. (2012). Parent and family impact of autism spectrumdisorders: a review and proposed model for intervention evaluation. Clinical Child and Family Psychology Review, 15, 247-277. doi: 10.1007/s10567-012-0119-6

Lawton, K., \& Kasari, C. (2012). Brief Report: Longitudinal improvements in the quality of joint attention in preschool children with autism. Journal of Autism and Developmental Disorders, 42, 307-312. Doi: 10.1007/s10803-011-1231-z

Maretha, R. D. (2012). Penerapan prinsip-prinsip developmental, individual-differences, relationship-based (DIR/Floortime) untuk meningkatkan keterampilan joint attention pada anak autism spectrum disorder (ASD) dengan Intellectual Disability. (Tesis). Universitas Indonesia, Depok.

Mash, E. J., \& Wolfe, D. A. (2010). Abnormal child psychology (4 ${ }^{\text {th }}$ ed.). Belmont: Wadsworth.

Mundy, P., \& Burnette, C. (2005). In F. R. Volkmar, R. Paul, R., A. Klin, A., \& D. Cohen. (2005). Handbook of Autism and Pervasive Developmental Disorder $3^{\text {rd }}$ volume 1: diagnosis, development, neurobiology, and behavior. Canada: John Wiley \& Sons, Inc.

Mundy, P., Delgado, C., Block, J., Venexia, M., Hogan, A., \& Seibert, J. (2003). Early social communication scales (ESCS): A manual for the abridged. University of Miami.

Mundy, P., \& Newell, L. (2007). Attention, Joint Attention, and Social Cognition. Curr Dir Psychol Sci, 16(5). doi: 10.1111/j.1467-8721.2007.00518.x

Mundy, P., \& Sigman, M. (2006). Joint attention, social competence, and developmental psychopathology. In Cicchetti \& Cohen, D (Eds.). Developmental psychopathology $2^{\text {nd }}$ edition volume. 1: Theory and Methods. Hoboken, NJ: Wiley. 
Mundy, P., Sigman, M., Ungerer, J., \& Sherman, T. (1986). Defining the social deficits of autism: the contribution of nonverbal communication measures. Journal of Child Psychology \& Psychiatry, 27: 657-669.

Mundy, P., \& Stella, J. (2000) Joint attention, social orienting, and nonverbal communication in autism. In A. M. Wetherby, \& B. M. Prizant (Eds.). Autism spectrum disorders: A transactional developmental perspective. Baltimore: Paul J. Brookes Publishing Co.

Plante, T. G. (2011). Contemporary Clinical Psychology $\left(3^{r d}\right.$ Ed). Hoboken: John Wiley \& Sons.

Shore, S. (2007). Dalam S. Myles, C. T. Swanson, J. Holverstott, \& M. M. Duncan. (Eds.). Autism spectrum disorders: a handbook for parents and professionals. London: Praeger.

Silva, L. M. T., \& Schalock, M. (2012). Autism parenting stress index: initial psychometric evidence. Journal of Autism and Developmental Disorder, 42, 566-574. doi: 10.1007/s10803-011-1274-1

Strauss, J. L., Guerra, V. S., Marx, C. E., Eggleston, M., \& Calhoun, P. S. (2010). Adherence and Psychotherapy. Dalam Bosworth, H. (Ed.). Improving Patient Treatment Adherence: A Clinician's Guide. New York: Springer.

Susanna. (2013). Penerapan Prinsip DIR/Floortime untuk Meningkatkan Kualitas Interaksi Ibu dan Anak dalam Rangka Mengembangkan Kemampuan Regulasi Diri Anak yang Menunjukkan Gejala Psikotik. (Tesis). Universitas Indonesia, Depok.

Timler, G. R. (2013). Interventions to support social communication skills. Dalam S. Goldstein, \& J. A. Naglieri. (Eds.). Interventions for Autism Spectrum Disorders. New York: Springer.

Van Hecke, A. V., Mundy, P. C., Acra, C. F., Block, J. J., Delgado, C. E., Parlade, M. V., Neal, A. R., Meyer, J. A., \& Pomares, Y. B. (2007). Infant Joint Attention, Temperament, and Social Competence in Preschool Children. Child Development, 78(1): 53-69. doi: 10.1111/j.1467-8624.2007.00985.x

Varanda, C. A., \& Fernandes, F. D. (2015). Assessing cognitive flexibility communication, social interaction and interest patterns of persons with autism as a basis for intervention. Psychology, 6, 387-392.

Volkmar, F. R., Lord, C., Bailey, A., Schultz, R. T., \& Klin, A. (2004). Autism and pervasive developmental disorders. Journal of Child Psychology and Psychiatry, 45(1), 135-170.

Wenar, C., \& Kerig, P. (2006). Developmental psychopathology: From infancy through adolescence (5 ${ }^{\text {th }}$ ed.). New York: McGraw-Hill.

Wilson, A. B. (2006). In M. Slade. \& S. Priebe. (Eds.). Choosing Methods in Mental Health Research: Mental health research from theory to practice. 